\title{
ON THE NECESSITY OF NECESSITY MEASURES: A RESPONSE TO ALAN O. SYKES
}

\author{
Anne van Aaken*
}

Applying economic theory to the analysis of economic "necessity" defenses in international law is highly desirable and Alan Sykes does a wonderful job in his editorial comment. ${ }^{1}$ As I have argued, the application of contract theory to international investment agreements (IIAs) helps us analyze their commitment and flexibility mechanisms. ${ }^{2}$ Sykes uses such an optimal contracting approach to address the problem of necessity in IIAs. I concur in broad terms with his conclusion, but I argue for greater contextualization in the application of the argument. Contract theory, although useful as a basic frame to address necessity claims, does not by itself fully encompass the economic analysis of law. Economic theory is diverse and not always unequivocal in its insights. Contract theory, as applied so far to international law, takes the state as a black box and assumes that the state will behave rationally. I will take a look into the box in order to analyze the incentives of different actors involved, including some of the beneficiaries of IIAs-foreign investors.

\section{A Question of Delegation: Observability, Verifiability, and the Expertise of Arbitrators in Cases of Necessity}

A general problem regularly discussed in investment law is the degree of delegation of interpretation to arbitrators. Three interconnected issues arise: first, the verifiability of the necessity; second, the self-judging nature of the necessity; and third, the economic expertise of arbitrators. Sykes correctly addresses the verifiability of the claimed facts of necessity. Moral hazard arises inter alia in instances of asymmetric information, such that the problem of verifiability is connected to the problem of credibility of pleaded facts. I agree with Sykes that this is not a big problem in economic necessity cases. Indeed, if the country has imposed hardship not only on foreign investors but also on its own population, the claim of necessity is credible. It also rebuts suspicion that the host state may have a discriminatory intent. This is especially the case if emergency laws are passed by the host state, as was the case in Argentina. It not only passed an emergency law in 2002 but also imposed considerable hardship on the population by freezing withdrawals of their dollar accounts totally and the peso accounts partially (so-called corralito). ${ }^{3}$ It would be highly unlikely that a host state would do that only in order to escape its obligations toward foreign investors. Thus, arbitrators can readily observe and verify the circumstances which allow for pleading of necessity, i.e. they can readily judge whether economic necessity exists.

Second, when drafting necessity clauses, the question arises how far arbitrators should scrutinize the economic policy measures taken by governments. Here, problems of the arbitrators' expertise come to the fore.

\footnotetext{
* Professor of Law and Economics, Legal Theory, Public International Law and European Law, University of St. Gallen.

Originally published online 23 December 2015.

1 Alan O. Sykes, Economic "Necessity" in International Law, 109 AJIL 296 (2015).

2 Anne van Aaken, International Investment Law Between Commitment and Flexibility: A Contract Theory Analysis, 12 J. INT'L ECON. L. 507

${ }^{3}$ Law No. 25561, Jan. 6, 2002 (Arg.).
} (2009). 
Arbitrators are "norm experts," not economic experts. This question arises twice: first, article 25 of the International Law Commission's (ILC) Articles on Responsibility of States for Internationally Wrongful Acts requires the adjudicator to judge whether the state "has contributed to the situation of necessity." 4 This assessment might make sense in many instances of necessity, but it is questionable if it makes sense for economic necessity except in cases of egregious economic behavior. Usually a state somehow contributes to a crisis-Greece did so, the United States did so before 2008, and the Asian states did so before 1998. The list could go on because with hindsight, we know much better what contributed to the crises. Ex ante, some policies are hard to judge-economics is not an exact science and economic policy measures are always disputed (just think about the controversy between F.A. von Hayek and Lord Keynes, which is still topical and watch this rap video ${ }^{5}$ if you have not yet done so). With hindsight, a tribunal will thus always find that the state contributed to the crisis, even though, to reach a fair judgment, an ex ante view should be taken. Moreover, even in cases such as price fluctuations of natural resources, which cannot be influenced by that very state, one can hold that it could have diversified its income or tried to hedge and thus "contributed to the situation of necessity." There is thus almost no choice for the tribunal but to affirm that the state contributed to the crisis. But a conditional requirement that must be answered always in the affirmative is not exactly conditional, and thus does not make much sense.

Similarly, article 25 of the ILC Articles requires that the measures taken were the "only way for the state to safeguard an essential interest against a grave and imminent peril." When full scrutiny is applied to the economic measures taken by governments, it is questionable whether arbitrators have enough economic expertise and should be second-guessing highly normative and politically laden policy choices. ${ }^{6}$ There are many ways of dealing with crises, many of them involving difficult distributive choices. In the Argentinian cases, most tribunals rather nonchalantly stated that there were other ways of dealing with the crisis. A tribunal would need to weigh all of the other (infinite) possibilities of crisis-mitigation measures and conclude that the measure taken was the only one possible to deal optimally with the necessity situation-which is impossible, even if the arbitrators were not lacking in significant economic expertise. Furthermore, since severe economic crises tend to lead to political crises, a prudent politician would take this into account as well (especially since political crises in turn tend to weaken the economy). I thus propose to follow Anne-Marie Slaughter in her expert opinion on the appropriate level of scrutiny to use in necessity analysis under Art. IX of the U.S.Argentinian Bilateral Investment Treaty (BIT), where she correctly argued (in my view) in the CMS Case for a good faith standard. ${ }^{8}$ The same test should be used in applying the customary international law norm reflected in article 25 of the ILC Articles. In both cases, it is highly questionable whether the arbitrators have enough economic expertise to judge the economic policies of a state. Usually, their expertise is in law, not in economics. And they usually do not work with economic experts to assess those questions in making their judgment.

${ }^{4}$ Draft Articles on the Responsibility of States for Internationally Wrongful Acts, Report of the International Law Commission on the work of its fifty-third session, 19 UN GAOR Suppl. No. 10, at 43, UN Doc. A/56/10 (2001), reprinted in [2001] 2 Y.B. Int'l L. Comm'n 26, UN Doc. A/CN.4/SER.A/2001/Add. 1.

${ }^{5}$ Emergent Order, "Fear the Boom and Bust" a Hayek vs. Keynes Rap Anthem, YouTubE (Jan. 23, 2010).

${ }^{6}$ Cf. also Sykes, supra note 1 , at 319.

${ }^{7}$ CMS Gas Transmission Company v. The Argentine Republic, ICSID Case No. ARB/01/8, Award, paras. 349 et seqq. (May 12 , 2005), 14 ICSID Rep. 158.

${ }_{8}^{8}$ On file with the author. 
There are several solutions to this problem, as I have argued elsewhere. ${ }^{9}$ So far, arbitral panels have either engaged in full scrutiny of alternatives in necessity cases or found that the clause is self-judging. Both choices are not optimal. On the one hand, fully self-judging clauses are easily misused and moral hazard is a problem (as Sykes argues on GATT Art. XXI; I would argue further that since investment law largely involves bilateral treaties, reputational effects mitigating the moral hazard problem are not as effective as under the GATT, and thus the reputational argument regarding why GATT article XXI was not often misused might not apply to investment $\left.\mathrm{law}^{10}\right)$. On the other hand, full scrutiny, as discussed above, would require much more economic expertise and does not respect difficult policy choices which are made in times of crisis, often by democratically elected governments (as in Argentina). Thus, a middle ground should be considered. I propose a "purpose-restricted" necessity clause. That is, the tribunal should fully review whether there is a case of economic necessity because that is easily verifiable. If the tribunal finds that this requirement is fulfilled, it should judge the measures taken by the state only on a good faith basis or not at all. The tribunal is thus restricted to the full review of the purpose of the norm (necessity). This approach differs from the approach of the GATT Panel in the Nicaragua case where the panel declined to even look at the United States' justifications. ${ }^{11}$ A different institutional solution would be to outsource the judgment on economic measures to expert bodies, such as a joint administrative commission created by the States Parties (as is foreseen in the U.S. Model BIT 2012 (article 20 (3)) ${ }^{12}$ and the Canadian FIPA 2004 (article 17) ${ }^{13}$ for financial market measures), thus addressing the expertise problem. Under this alternative, from a contract theory perspective, the States Parties withdraw the delegation of resolving certain questions (e.g. prudential regulation of financial markets or economic crises measures) from the tribunal ex ante and delegate them instead to specialized agencies of the States Parties holding the relevant expertise. If both agencies find that the measures were appropriate, the tribunal needs to accept them. The more independent from government the agencies are (e.g. the central banks), the more credible this solution is for investors. If one state finds that the measures were not (such as the home state), the tribunal would decide. It might also be possible to draw on the expertise of international financial institutions (IFIs), such as the International Monetary Fund (IMF); either by inviting them as experts or by outsourcing the judgment concerning the economic necessity requirements to them. The latter has the advantages of both economic expertise and greater neutrality compared to state institutions.

\section{Firms and their Incentives}

In analyzing investment law, scholars commonly look at the incentives of the host and the home states. Surely, these are the main players in treaty drafting. But when it comes to interpretation, the incentives of the benefitted third party should be taken into account as well. Situations of economic crisis are usually situations of legal transition; many laws and regulations are issued in order to cope with crises, often ad hoc. As the lawand-economics scholar Louis Kaplow argued convincingly almost thirty years ago, uncertainty concerning

${ }^{9}$ Anne van Aaken, Smart Flexibility Clauses in International Investment Treaties and Sustainable Development: A Functional View, 15 J. WorLD INV. \& TRADE 827 (2014) and Anne van Aaken, Control Mechanisms in International Investment Law, in THE FOUNDATIONS OF International Investment Law: Bringing Theory into Practice 409 (Zacharias Douglas et al. eds., 2014).

10 Sykes, supra note 1 , at 303.

11 Panel Report, United States-Nicaraguan Trade, para. 5.3, L/6053, Oct. 13 1986. The Panel outlined the self-judging nature clearly:

The Panel concluded that, as it was not authorized to examine the justification for the United States' invocation of a general exception to the obligations under the General Agreement, it could find the United States neither to be complying with its obligations under the General Agreement nor to be failing to carry out its obligations under that Agreement.

12 2012 U.S. Model Bilateral Investment Treaty.

132004 Canadian Model Foreign Investment and Protection Agreement. 
government action is in many respects like other types of uncertainty. ${ }^{14}$ The relevant questions are, thus, who bears the costs of uncertainty and how are incentives affected by shifting these costs. Moral hazard and opportunism in contractual relationships are not the exclusive domain of states. To the extent that insurance (read: IIAs) covers losses, actors have less incentive to avoid them, either by taking actions that diminish the probability of loss or by behaving in a manner that reduces the amount of loss. Kaplow argues that the market is best to strike the appropriate balance between mitigating risk and preserving incentives. Thus, relying on the market to address the effects of changes in government policy often seems more efficient than requiring government relief through compensation to the investor. Let us return to the example of Argentina and take the perspective of a diligent investor. Even before the crisis struck in 2001, Argentina was a highly unstable country for more than half a century. It has always oscillated between neoliberal economic policies, on the one hand, and mercantilist, import substituting and nationalizing policies plagued by hyperinflation, on the other hand. ${ }^{15}$ Even when in 1990 (not 1992; I was in Argentina and could see the immediate effect), the peg to the dollar was introduced in order to end hyperinflation and Argentina was following the "Washington Consensus" advice of IFIs, it would have been highly naïve to believe this would turn Argentina suddenly into a model student of good economic policy resulting in stability with low inflation and a secured peg to the dollar over the next 35 years (the duration of most of the contracts which were adjudicated upon in the Argentinian necessity cases). In the first case on necessity, the CMS case, the company had taken on debt denominated in U.S. dollars, which then led to its inability to pay its creditors when its income suddenly was tied to the devalued peso. ${ }^{16}$ Its managers seemed to have believed either that over the next 35 years the peg to the dollar would hold at a 1:1 parity or that the concession contract together with the bilateral investment treaty (BIT) shifted the risk to the country in times of crisis, thus, insuring against currency risk.

Although the tribunal held in its decision on jurisdiction that "Bilateral Investment Treaties are not insurance policies against bad business judgments"17 (citing Maffezini v. Spain ${ }^{18}$ ), insuring bad or at least quite imprudent business judgment is exactly the consequence of the CMS tribunal's decision on the merits. What would a diligent merchant have done? Before investing, the country risk should be taken into account, including the risks of the country's monetary policy, especially concerning exchange rates. Since hedging currency risks is a classic tool of foreign investors, one is left wondering why this tool was not used by TGN (the local company). One is also left wondering why the debt was taken in U.S. Dollar and not in pesos, since credit was available in Argentina in the 1990s and diligent investors usually prefer to take their debt in the local currency. Speaking frankly, a manager taking such a decision should have been fired.

Another topic obviously overlooked by the tribunals is the market principle of risk and return. Riskless high returns usually smell. And this is what happened in Argentina - the returns in the 1990s were high. That is justified if and only if risk is present as well. If the risk realizes, this risk should belong to the investor (she got the high returns before). But the tribunals shifted it to the country with the consequence that investors got doubly reimbursed: first by high returns and second by damage awards (if paid).

Furthermore, one can argue that in those cases the investor is most likely the cheapest insurer, which is an important criterion in the economic analysis of law to evaluate normatively who should bear the risk of certain unforeseen circumstances. According to this concept, it is efficient if the person who most cheaply

${ }^{14}$ Louis Kaplow, An Economic Analysis of Legal Transactions, 99 HARV. L. REv. 509 (1986).

15 Sykes, supra note 1 , at 316 .

${ }^{16}$ CMS Gas Transmission Company v. The Arg. Republic, ICSID Case No. ARB/01/8, Award, paras. 69 et seqq. (May 12, 2005), 14 ICSID Rep. 158.

${ }^{17}$ CMS Gas Transmission Company v. The Arg. Republic, ICSID Case No. ARB/01/8, Decision of the Tribunal on Objections to Jurisdiction (July 17, 2003), 7 ICSID Rep. 494.

${ }^{18}$ Emilio Agustín Maffezini v. The Kingdom of Spain, ICSID Case No. ARB/97/7, Award (Nov. 13, 2000), 5 ICSID Rep. 419. 
can insure the damage bears the damage. The investor knows best what risks she needs to insure in order to make a viable investment. Reimbursing investors in times of necessity for typical economic risks diminishes their incentive to hedge against these risks, such as currency risks, which usually are part of normal business, ${ }^{19}$ and may encourage inefficient overinvestment. ${ }^{20}$ Furthermore, many of the Argentinian cases involved priceregulated industries and such industries are always problematic. In the tribunals' decisions, it was remarkable that, when calculating damages, they did not include the counterfactual of an unregulated market and thus assess what the price would have been in an economic crisis without price regulation. Energy prices, for example, are the first to decline when demand is weak (as in times of crisis) and profits in that sector would fall accordingly. This kind of economic cycle risk should be borne by the economic operator.

\section{Deferred (Partial) Compensation of Investors?}

In principle, there are two possibilities regarding compensation if necessity is found: either no compensation is due or the compensation is postponed. Sykes proposes a partial compensation by deferring the payment and potentially applying reduced interest rates. I tend to agree with him, although subject to some significant caveats. First, from a business perspective, deferral is not necessarily attractive. Accounting rules, such as IAS 40, demand a write-down or respective correction of the value of claims; that is, if it is more likely than not that the investor will not be paid, the loss needs to be realized on the books immediately. Even if a write down were not mandated by accounting rules, prudent accounting would demand writing down any claim (also a bond claim, in case the claim is converted) against a very unstable country (taking account of the country risk rating). Thus, it does not make a big difference (in the books) whether there is deferred payment by a high-risk country or whether there is no payment (unless the claim is sold on the secondary market with a heavy haircut).

Second, the other problem with postponed compensation is the long-term recovery of the host state. Many countries suffering from economic crises have unsustainable levels of debt. ${ }^{21}$ Deferring the compensation means that money needs to be available to pay the investors - if not now, then later. As Sykes points out, this debt entails opportunity costs in the form of foregoing the provision of public services and infrastructure investment.22 This choice affects, for example, health and education, which both involve investments for the country's long-term growth prospects. Additionally, the country may need to forsake its international human rights commitments, especially under the UN Covenant on Economic, Social and Cultural Rights. Having unsustainable levels of debt in the books (even if not payable immediately) also affects the rate at which a country can borrow on international capital markets, thereby curtailing its ability to spend on growthpromoting measures in the future, potentially prolonging the crisis. Policymakers tried to tackle the problem of highly indebted countries in 1996 through the heavily indebted poor countries (HIPC) Initiative initiated by the IMF and the World Bank. ${ }^{23}$ The underlying arguments behind this initiative remain valid even for countries that are not the poorest.

I would thus, in principle, follow Sykes' proposal of deferred and reduced compensation, but I would plead for differentiation with respect to the contributing behavior of the investor, the sector in question, the further circumstances of the country, and the country's sustainable development prospects. If the amount of the

\footnotetext{
${ }^{19}$ See also Sykes, supra note 1, at 302, for the U.S. contract law.

${ }^{20} \underline{I d}$. at 321 .

21 Id. at 312 .

22 Id. at $309,312$.

${ }^{23}$ Heavily Indebted Poor Country (HIPC) Initiative, The World Bank.
} 
damage could have been avoided by the investor (e.g. by taking out insurances), if the investment took place at a time where the respective country was already a high risk (question of legitimate expectations), and if the investment was in a sector which is highly volatile due to economic cycles (e.g. energy or natural resources), the damage claim should be reduced to a larger extent (since the investor presumably would have suffered from losses anyhow). As regards the country, considerations of the past such as whether the country adhered to reasonable economic policies (e.g. IMF advice), whether the economic necessity was also caused by international economic imbalances (e.g. exogenous shocks such as contagion), and whether its policies were the result of democratic decision-making, should be taken into account. Considering the prospects of the country's sustainable development would be another factor. If the level of growth enhancing policies such as investment in infrastructure, public health, and education would have to be cut to an extent that would produce a "lost generation," this factor merits further reduction of the claims. Those considerations would take into account the incentives and the avoidance of moral hazard of both the investor and the host state, and allow for a more fine-tuned treatment of economic necessity cases. 